\title{
辡丸機能不全症の診断と治療
}

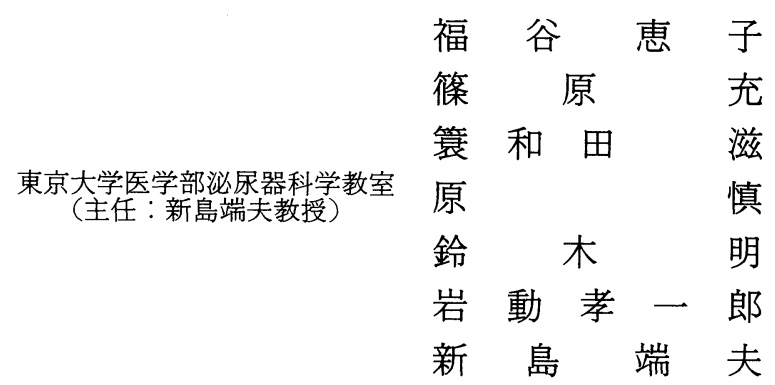

\section{DIAGNOSIS AND TREATMENT OF MALE HYPOGONADISM}

\author{
Keiko Fukutani, Mitsuru Shinohara, Shigeru Minowada, Makoto Hara, \\ Akira Suzuki, Koichiro Isurugi and Tadao Niijima \\ Department of Urology, Faculty of Medicine, The University of Tokyo
}

(Director: Prof. T. Niijima)

\begin{abstract}
Sixty-seven patients with Klinefelter's syndrome (KS) and 69 patients with hypogonadotoropic eunuchoidism (HE) were comparatively studied as to clinical symptoms, endocrinological tests, testicular histology and therapeutic results. Generally in the HE group the age at first visit was younger and the signs of hypogonadism were more manifest than in the KS group. Cryptorchism ocurred more frequently in $\mathrm{HE}$, and gynecomastia was found more often in KS. In chromosome analysis all KS patients had the XXY cell line and all HE patients analysed showed 46, XY karyotype. Basal serum LH and FSH as well as their responses to $\mathrm{LH}-\mathrm{RH}$ were definitely high in $\mathrm{KS}$ and only minimal in HE. Some KS patients revealed normal serum testosterone $(\mathrm{T})$ levels although the average $\mathrm{T}$ level of KS was decreased. The HE patients showed a significantly lower $\mathrm{T}$ level than the KS. Serum $\mathrm{T}$ responses to exogenous hCG were smaller in KS than in normal males and they were more diminished in HE. However, some HE patients who had low basal T levels responded appreciably to hCG stimulation. Serum PRL levels were abnormally elevated only in two HE patients with pituitary tumor. The histology of the testis showed tubular hyalinization and Leydig cell hyperplasia in almost all of KS patients. In contrast, spermatogenesis up to spermatocyte, spermatid or spermatozoa were observed approximately in one third of the HE patients, although the majority of $\mathrm{HE}$ patients showed prepubertal findings of testicular histology. Since improvement of sperm production is hopeless in KS, T replacement therapy was applied to those with poor secondary sexual characteristics. The HE patients were treated with hCG after careful clinical observation and repeated hormone studies. When hCG therapy did not attain sexual maturation in HE, treatment was switched to $\mathrm{T}$ replacement.
\end{abstract}

要旨：Klinefelter 症候群（KS）67例と低ゴナドトロピン性類宦官症 (HE) 69例を対象に臨床像, 内分 泌検査成績, 辠丸組織像および治療成績について比較検討した. HEは KSょり一般に性器発育不全の程 度が強く, 受診年齢が若かった。停留辡丸の合併は HE に多く, 女性化乳房は KS に多かった. 染色体 分析では KS は全てXXY の cell line を持ち, HEでは分析した全例46XYであった. 血中 LH, FSH 抒 よび LH-RH に対する反応は KS では正常男子ょり高く，HEでは低かった，血中 testosterone (T) 值 は KS では正常男子ょり低いが，正常範囲にあるものも存在し，HEでは KSより更に低かった。 また hCG に対するT の反応は KS では正常男子より小さく HEでの反応は KSより更に小さかったが, 反応 率は正常男子より大きかった。血中 prolactin 值は下垂体腫瘍を伴う 2 例の HE のみで異常高值を示し た. 睪丸組織像は KS では大多数が精細管硝子化, Leydig 細胞増生, 生殖細胞消失を示し, 生殖細胞が 
僅かに保たれているものが少数存在した. HEでは小児様の䁄丸組織像を認めるものが多がったが，1/3 近くの症例で精母細胞から精子に至るまでの造精過程の発現を見た。 KS では二次性徵のほぼ完全なも のにはホルモン療法は行わず，性器発育不全を示すもののみにT補充療法を行った，HEでは一定期間， 内分泌検査を繰り返し臨床像を観察した後, まず hCG 療法を始め, 二次性徵発現, 造精機能に効果のな い場合にはT療法に変更した。

はじめに

殬丸機能不全症 male hypogonadism は類宦官症 eunuchoidism ともいい，思春期に抢ける辠丸の成熟 障害を主徴とする症候群の総称である。これには睪丸 原発性の障害による疾患と，上位中枢である間脳一下 垂体系の障害による続発性の疾患が存在する。原発性, 続発性の両者とも症状としては性器および二次性徵の 発育不全を示すので，臨床症状だけからではそれらの 鑑別は必ずしも容易でない，乙かしそれぞれに特徵的 な内分泌検査所見を示しまた治療方針も異なるので, 類宦官症の診療に当って両者を厳密に鑑別する必要が ある．著者らは原発性睪丸機能障害の代表的疾患であ る Klinefelter 症候群67例と間脳一下垂体障害による 低ゴナドトロピン性辠丸機能不全症69例の自験例につ いて, それらの臨床像, 内分泌検査所見, 奠丸病理組 織所見，治療法抢よびその成績について比較検討した のでここにのべる，さらにゴナドトロピン単純欠損に よる類宦官症としばしば鑑別困難な思春期遅延症およ び fertile eunuch 症候群と考号られる症例を 1 例ずつ 経験したのでこれらの疾患が低ゴナドトロピン性粹丸 機能不全症の中でしめる位置について考察を加えた い.

\section{対象症例}

東京大学医学部泌尿器科招よび同附属病院分院泌尿 器科において，1963年より1983年の21年間に経験した Klinefelter 症候群 (KS) 67例と低ゴナドトロピン性類 宦官症 (HE) 69例を今回の研究対象とした。後者のう ち分けはゴナドトロピン単独欠損症58 (Kallmann 症 候群 9 例を含む)，下垂体小人症 6 , 下垂体腫瘍 2 (術 前, 術後各 1 例), Froelich 症候群 1 , fertile eunuch 症候群 1 打よび思春期遅延症 1 である。

\section{方法}

1）辠丸容量測定には武井医科光器製作所製オルキ ドメーターを使用した。鼻丸の径をノギスで測定して 大きさを記載されていた症例では，これをオルキド メーターに換算した。

2）末梢血リンパ球培養による染色体分析は, 東京医 科歯科大学細胞遺伝学教室または相互生物医学研究所
で行った.

3) 血中 testosterone ( $T$ ), luteinizing hormone (LH) おょび follicle stimulating hormone (FSH) の測定は当教室においてラジオイムノアッセイ(RIA) で行った ${ }^{122}$. 正常成年男子に括ける平均値执よび標準 偏差は以下の通りである. 括弧内は対象数を示す。 $\mathrm{T}$ $537 \pm 102 \mathrm{ng} / \mathrm{dl}$ (15), LH $21.2 \pm 8.8 \mathrm{ng} / \mathrm{ml}(40), \quad$ FSH $73.2 \pm 32.5 \mathrm{ng} / \mathrm{ml}(40)$. 血中 prolactin (PRL) および 一部の症例に拈ける血中 LH, FSH 值の測定は北里バ イオケミカルラボラトリーに依頼し RIA でおこなっ た。

4）尿中ゴナドトロピン值の測定は帝国藏器製薬臨 床検査所に依頼し，カオリン吸着マウス子宮重量法 （Bradbury一松島变法）により行った。

5）LH-RH 試験は合成 luteinizing hormonereleasing hormone（LH-RH ${ }^{\circledR}$ 田辺，またはルタミン ®，第一) $100 \mu \mathrm{g}$ を静注投与し，投与前拉よび投与後 30 分に採血して LH および FSH 值を測定した ${ }^{2)}$. 正常成 年男子11名に括ける基礎值 $\left(0^{\prime}\right)$ 打よび反応值 $\left(30^{\prime}\right)$ の平均值および標準偏差は下記の通りである. $\mathrm{LH}\left(0^{\prime}\right)$ $20.1 \pm 9.6 \mathrm{ng} / \mathrm{ml}, \mathrm{LH}\left(30^{\prime}\right) 153.4 \pm 100.0 \mathrm{ng} / \mathrm{ml}, \mathrm{FSH}$ ( $\left.0^{\prime}\right) 104.1 \pm 38.5 \mathrm{ng} / \mathrm{ml}$, FSH (30') $183.1 \pm 78.3 \mathrm{ng} /$ $\mathrm{ml}$.

6） HCG 試験はヒト胎盤性ゴナドトロピン（ゴナト ロピン®, 帝国臓器) 5000 単位を 4 日間連続筋注し, 投 与前拈よび筋注 24 時間後に採血して血中T值を測定し

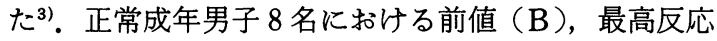
值 $(\mathrm{M})$ ，反応差 (M-B), 反応率 $\{(\mathrm{M}-\mathrm{B}) / \mathrm{B}\}$ の平均 值および標準偏差は下記の通りである，B $527 \pm 100$ $\mathrm{ng} / \mathrm{dl}, \mathrm{M} 1,148 \pm 402 \mathrm{ng} / \mathrm{dl}, \mathrm{M}-\mathrm{B} 609 \pm 313 \mathrm{ng} / \mathrm{ml}$, (MB) $/$ B $113 \pm 49 \%$.

7) TRH 試験は thyrotropin-releasing hormone, TRH（プロチレリン®，田辺） $500 \mu \mathrm{g}$ を静注し，その 投与前怙よび投与後15分，30分で採血してPRLを測 定した。

8）テストステロン補充療法としてはテストステロ ンデポ剂（エナルモンデポ®，帝国藏器） 100 １25mg を週 1 回筋注投与し, 臨床効果を観察しつつ漸次 2 週 
〜 4 週 1 回の投与の間隔にした.

9）ゴナドトロピン刺激療法はゴナトロピン®, 1,000IU を週 2 3 回, または2,000IU, 5,000IUを週 2 回筋注投与した.

\section{結果}

I 、臨床所見

受診時の主訴を $\mathrm{KS}, \mathrm{HE}$ に分けて表 1 に示した. $\mathrm{KS}$ では性器発育不全を主訴とするものが32例(48\%), 不 妊を主訴とするものが28例（42\%）とほぼ同数である のに対し, HE では性器発育不全が55例 (80\%) と圧倒 的に多く不妊を主訴とするものは 1 例のみであった。 なお KS67例中28名の半数近くが既婚であったが, $\mathrm{HE}$ 69例中既婚者は 1 名のみであった。

$\mathrm{KS}, \mathrm{HE}$ 両群の初診時年齢, 身長, 体重, 殬丸重量, 陰茎の長さを表 2 に示した。ささらに両群の耽毛発育の 程度をTannerの分類占で示し，また停留辠丸と女性 化乳房の発生頻度を記載した。

初診時の平均年齢は $\mathrm{KS}$ では 28 歳で, 10 代の症例は 7 名存在した. $\mathrm{HE}$ では平均 24 歳で, 10 代の患者は 16 名

Table 1 Chief complaint

\begin{tabular}{l|c|c}
\hline & $\begin{array}{l}\text { Klinefelter's } \\
\text { syndrome }\end{array}$ & $\begin{array}{l}\text { Hypogonadotropic } \\
\text { eunuchoidism }\end{array}$ \\
\hline infantile genitalia & $32(48 \%)$ & $55(80 \%)$ \\
infertility & $28(42 \%)$ & $1(1 \%)$ \\
impotence & $1(1 \%)$ & $1(1 \%)$ \\
short stature & $0(0 \%)$ & $5(7 \%)$ \\
cryptorehism & $0(0 \%)$ & $2(3 \%)$ \\
others & $6(9 \%)$ & $5(7 \%)$ \\
\hline & 67 & 69 \\
\hline
\end{tabular}

ありこれらに対しては 2 年以上の経過観察を行って いる，初診時年齢は HEが KSより有意に若かった $(\mathrm{p}<0.01)$. 身長, 体重拉よび陰茎の長さの平均はいず れも $\mathrm{HE}$ では $\mathrm{KS}$ より小さかった $(\mathrm{p}<0.05)$. 辠丸重 量の平均でも $\mathrm{HE}$ が $\mathrm{KS}$ よりさい傾向が認められた がこれには有意差がなかった。耽毛の発育はHEでは 小児様の PH 1が半数以上で成人男子に近い PH 4 5 は $6 \%$ とごくわずかであるのに対し, KS では PH 1は 9 \%とむしろ少なく PH 2 3 64\%, PH 4〜5 26\%で 耽毛発育は KS が HEより良好であった $(\mathrm{p}<0.05)$. 停留辠丸の合併は $\mathrm{KS}$ では 5 例 ( $8 \%$ ）, HE では11例 (16\%)で KS の 2 倍であり，また KS では全例一側性 であったが, HE では 6 例, 半数以上が両側性であっ た. 女性化乳房は KS では $29 \%$ と約1/3に認められたが HEでも19\%に認められ，これらの発生頻度には有意 差はなかった。 その他の合併症として KS に知能低下 が 3 例, 精神病が 2 例あり, HE には嗅覚消失, 低下が 9 例, 難聴が 2 例, 色弱が 1 例に認められた。家族歴 としては KS で染色体48, XXXY を示す一卵性双生児 の 1 組があり, また HEでも下垂体性小人症の兄弟例 が 1 組存在した。

II. 検査成績

1）染色体分析の結果を表 1 に示す. KS では67例全 例に分析がなされている。その結果は $47, \mathrm{XXY} \mathrm{が63}$ 例, $48, \mathrm{XXXY}$ が 2 例, 他の 2 例はモザイクでともに 47, XXY の cell line 有していた. HEでは69例中22 例の及に検查が施行され，これらはすべて46, XYで あった。

2）治療前の血中 $\mathrm{T}, \mathrm{LH}, \mathrm{FSH}$ 値を $\mathrm{KS}, \mathrm{HE}$ 別に 図 1 に示した。各群に拈けるそれぞれのホルモンの平

Table 2 Clinical findings

\begin{tabular}{|c|c|c|}
\hline & $\begin{array}{l}\text { Klinefelter's } \\
\text { syndrome }\end{array}$ & $\begin{array}{l}\text { Hypogonadotropic } \\
\text { eunuchoidism }\end{array}$ \\
\hline $\begin{array}{l}\text { age at first visit }(\mathrm{yr}) \\
\text { body height } \quad(\mathrm{cm}) \\
\text { body weight } \quad(\mathrm{kg}) \\
\text { testicular weight }(\mathrm{g}) \\
\begin{array}{l}\text { penile length } \quad(\mathrm{cm})\end{array}\end{array}$ & $\begin{array}{r}28 \pm 7(67) \\
169 \pm 7(58) \\
63 \pm 13(54) \\
3.7 \pm 3.2(58) \\
4.3 \pm 1.1(64)\end{array}$ & $\begin{array}{r}24 \pm 6(69) \\
162 \pm 13(62) \\
57 \pm 14(58) \\
3.2 \pm 2.9(64) \\
3.4 \pm 0.9(67)\end{array}$ \\
\hline & Mean $\pm \mathrm{SD}(\mathrm{No})$ & Mean $\pm \mathrm{SD}(\mathrm{No})$ \\
\hline $\begin{array}{l}\text { pubic hair growth } \\
\quad \text { (Tanner's } \\
\text { classification) }\end{array}\left\{\begin{array}{l}\text { PH } 1 \\
\text { PH } 2-3 \\
\text { PH } 4-5\end{array}\right.$ & $\begin{array}{r}5 / 53(9 \%) \\
34 / 53(64 \%) \\
14 / 53(26 \%)\end{array}$ & $\begin{array}{r}32 / 62(52 \%) \\
26 / 62(42 \%) \\
4 / 62(6 \%) \\
\end{array}$ \\
\hline $\begin{array}{l}\text { cryptorchism } \\
\text { gynecomastia }\end{array}$ & $\begin{array}{r}5 / 66(8 \%) \\
19 / 66(29 \%)\end{array}$ & $\begin{array}{l}11 / 68 \quad(16 \%) \\
13 / 68 \quad(19 \%)\end{array}$ \\
\hline
\end{tabular}


Table 3 Chromosome

\begin{tabular}{c|c}
\hline Klinefelter's syndrome & \\
\hline 47, XXY & 63 \\
$48, \mathrm{XXXY}$ & 2 \\
$46, \mathrm{XY} / 47, \mathrm{XXY}$ & 1 \\
$47, \mathrm{XXY} / 49, \mathrm{XXXXY}$ & 1 \\
\hline Hypogonadotropic eunuchoidism & 67 \\
\hline 46, XY & 22 \\
not analysed & 47 \\
\hline
\end{tabular}

図 1 血中テストステロン, LH，FSH 值を Klinefelter 症候群 (KS) と低ゴナドトロピン性類宦 官症 (HE) 別に示した。 カラムはそれぞれの群の平 均值，網かけの部分は成年男子の正常値を示す。

Basal Hormone Levels
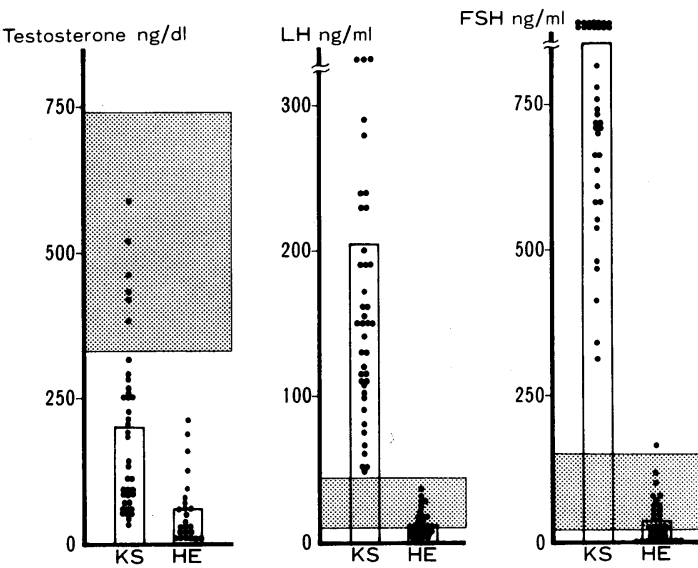

均值と標準偏差を示し，測定した症例数を括弧内に示 す. Tは KS $191 \pm 143 \mathrm{ng} / \mathrm{dl}$ (41), HE $59 \pm 12 \mathrm{ng} / \mathrm{ml}$

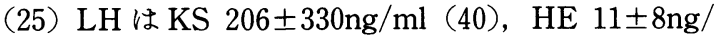

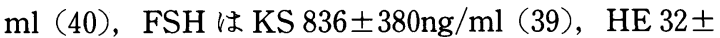
$37 \mathrm{ng} / \mathrm{ml}$ (40)であった。 Tの平均値は KS では正常男 子より有意に低いが $(\mathrm{p}<0.01)$, 症例によりばらつき があり, 正常範囲にあるものも 6 例存在した. HEの T 値は KSより有意に低かった $(\mathrm{p}<0.01) . \mathrm{LH}, \mathrm{FSH}$ 值 はともに KS では正常男子より有意に高く， HEでは 正常男子より有意に低かった（ともに $\mathrm{p}<0.01$ ).

血中ゴナドトロピン値の測定を北里バイオケミカル ラボラトリーで行った KS 12例, HE 5 例では, LH, $\mathrm{FSH}$ とも $\mathrm{KS}$ ではそれぞれの正常上限 $34.5 \mathrm{mIU} /$

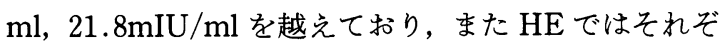

図 2 LH-RH 試験の結果を Klinefelter 症候群は白 丸で, 低ゴナドトロピン性類宦官症は黒丸で示した。
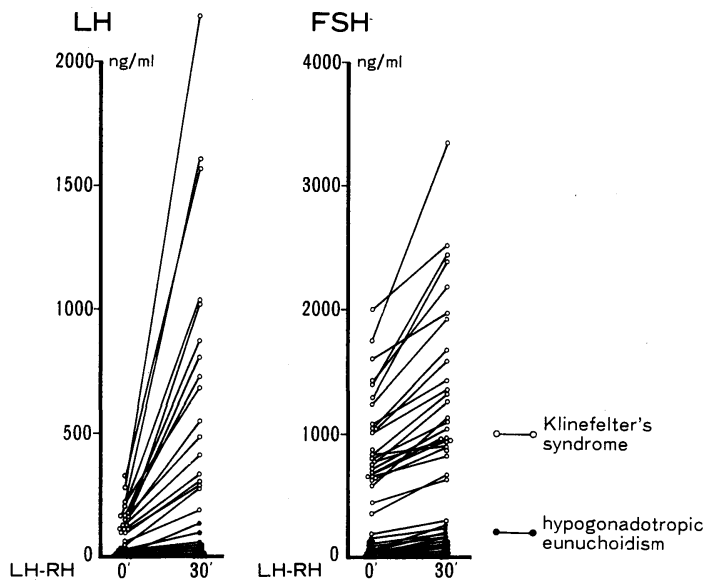

れの正常下限 $6.5 \mathrm{mIU} / \mathrm{ml}, 1.9 \mathrm{mIU} / \mathrm{ml}$ 以下であった。 さらに KS 8 例， HE 13例に执いてはゴナドトロピン の測定を24時間尿中ゴナドトロピン排泄量により行っ た，KS では全例 $48 \mathrm{~m} . \mathrm{I} . \mathrm{U}$. 以上， HEではすべて6m.I. U. 以下であった。

3） LH-RH 試験は KS 27例，HE 34例に行い，その 成績を図 2 に示した. KS では $\mathrm{LH}\left(0^{\prime}\right) 163 \pm 85 \mathrm{ng} / \mathrm{ml}$, LH (30') $686 \pm 471 \mathrm{ng} / \mathrm{ml}$, FSH $\left(0^{\prime}\right) 163 \pm 85 \mathrm{ng} / \mathrm{ml}$, $\mathrm{FSH}\left(30^{\prime}\right) 1,408 \pm 705 \mathrm{ng} / \mathrm{ml}$ であり, HE では LH $\left(0^{\prime}\right)$ $10 \pm 6 \mathrm{ng} / \mathrm{ml} \pm, \quad \mathrm{LH}\left(30^{\prime}\right) 30 \pm 28 \mathrm{ng} / \mathrm{ml}, \quad \mathrm{FSH}\left(0^{\prime}\right) 34 \pm$ $36 \mathrm{ng} / \mathrm{ml}, \mathrm{FSH}\left(30^{\prime}\right) 80 \pm 65 \mathrm{ng} / \mathrm{ml}$ であり, LH, FSH とも KS では正常男子と比較して過剩反応，HEでは 著しい反応低下を示した。 Fertile eunuch 症候群の 1 例では血中 LH, FSH 值执よび LH-RH に対するそれ らの反応は正常であった。

4) HCG 試験は KS 12例，HE 17例に打いて行い, その結果を図 3 に示した. KS の $\mathrm{T}$ 基礎値 (B)は $152 \pm$ $104 \mathrm{ng} / \mathrm{dl}$ ，最高反応值（M）は256 $\pm 153 \mathrm{ng} / \mathrm{ml}$ で，正 常男子に比べてともに有意に低く $(\mathrm{p}<0.01)$ ，また $\mathrm{HE}$ ではB $56 \pm 57 \mathrm{ng} / \mathrm{ml} ， \mathrm{M} 167 \pm 126 \mathrm{ng} / \mathrm{ml}$ でともに KS よりさらに低かった $(\mathrm{p}<0.01)$. しかし HEでは基礎 值の低いにも拘わらず反応のよい症例もあり，最高反 応率 (M-B/B) は $544 \pm 733 \%$ で正常男子より大きかっ た $(\mathrm{p}<0.05) . H E の$ 中で四角印で示した fertile eunuch 症候群の 1 例は基礎值 $30 \mathrm{ng} / \mathrm{dl}$ から最高値339 $\mathrm{ng} / \mathrm{dl}$ に上昇した。

5）PRL の前値および TRH 試験の結果を図 4 に示 した. KS に怙ける正常值, 標準偏差拈よび症例数は以 
図 $3 \mathrm{HCG}$ 試験の結果を Klinefelter 症候群 (KS), 低ゴナドトロピン性類宦官症 (HE) 別に示した。網 かけの部分は正常成年男子の反応である，HE中四 角印で示した 1 例は fertile eunuch 症候群である。

4-Day HCG Test
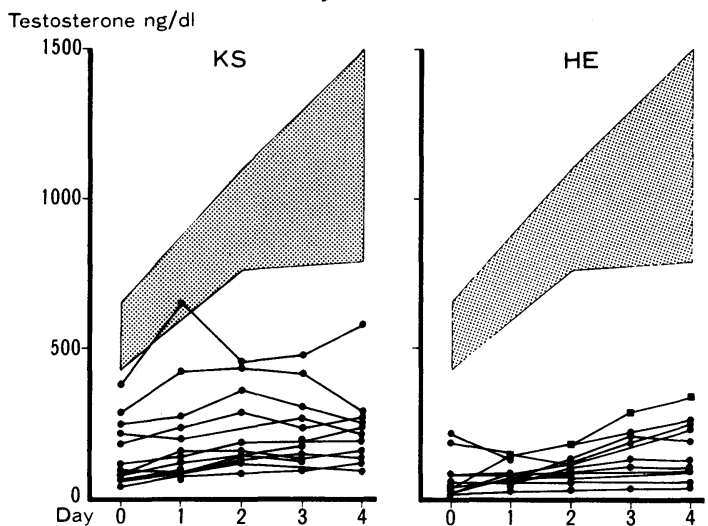

図 4 血中 PRL 值および TRH 試験の結果を Klinefelter 症候群 (KS) と低ゴナドトロピン性類宦 官症（HE）別に示した。

\section{PRL \& TRH Test}
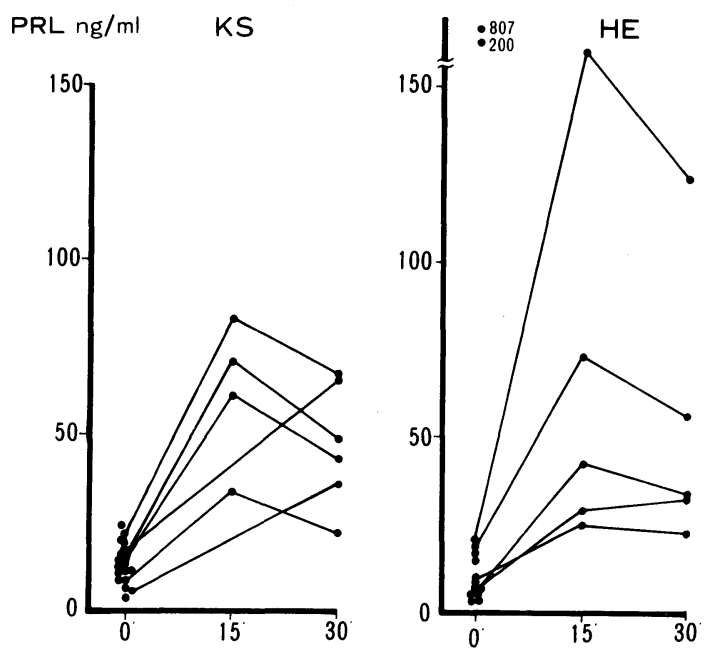

下のと拈りである. PRL ( $\left.0^{\prime}\right) 12.7 \pm 5.6 \mathrm{ng} / \mathrm{ml}(16)$, PRL (30') 47.3土16.2ng/ml (6) で正常男子の結果 ${ }^{4)}$ と差がなかった。 HEの 2 例では PRL $\left(0^{\prime}\right) 200 \mathrm{ng} / \mathrm{ml}$, $807 \mathrm{ng} / \mathrm{ml}$ がそれぞれ PRL (30’) $243 \mathrm{ng} / \mathrm{ml}, 1,133 \mathrm{ng} /$ $\mathrm{ml}$ と異常高值をしめした。これらはともに下垂体腫瘍 の患者である。他の 5 例では PRL ( $\left.0^{\prime}\right) 10.2 \pm 5.5 \mathrm{ng} /$ $\mathrm{ml}, \mathrm{PRL}\left(30^{\prime}\right) 53.3 \pm 7.0 \mathrm{ng} / \mathrm{ml}$ と正常範囲にあった.

6）精液採取は KS 26名，HE 2 名で可能であり，精
Table 4 Histology of testis

\begin{tabular}{|c|c|c|c|c|}
\hline \multicolumn{5}{|c|}{ Klinefelter's syndrome } \\
\hline \multicolumn{4}{|c|}{$\begin{array}{l}\text { tubular hyalinization, no germinal cell, } \\
\text { no Sertoli cell, no Leydig cell }\end{array}$} & 4 \\
\hline \multirow{6}{*}{$\begin{array}{l}\text { tubular } \\
\text { hyalinization } \\
\text { and } \\
\text { Leydig cell } \\
\text { hyperasia }\end{array}$} & \multicolumn{2}{|c|}{$\begin{array}{l}\text { no germinal cell, } \\
\text { only Sertoli cell } \\
\text { spermatogenesis } \\
\text { arrest with }\end{array}$} & \multirow{6}{*}{$\begin{array}{l}\text { no Sertoli cell } \\
\left\{\begin{array}{l}\text { spermatogonia } \\
\text { spermatocyte } \\
\text { spermatid } \\
\text { spermatozoa }\end{array}\right.\end{array}$} & 36 \\
\hline & & & & 3 \\
\hline & & & & 3 \\
\hline & & & & 2 \\
\hline & & & & 1 \\
\hline & & & & 1 \\
\hline \multicolumn{5}{|r|}{50} \\
\hline \multicolumn{5}{|c|}{ Hypogonadotropic eunuchoidism } \\
\hline \multicolumn{4}{|c|}{$\begin{array}{l}\text { immature tubule, no spermatogenesis, } \\
\text { no Leydig cell }\end{array}$} & 37 \\
\hline \multirow{3}{*}{\multicolumn{2}{|c|}{ spermatogenesis up to }} & \multicolumn{2}{|c|}{$\begin{array}{l}\text { spermatocyte } \\
\text { spermatid } \\
\text { spermatozoa }\end{array}$} & 8 \\
\hline & & & & 4 \\
\hline & & & & 3 \\
\hline & & & & 52 \\
\hline
\end{tabular}

液検査を行ったが全例無精子症であった。

7）睪丸生検による組織学的検查は KS 50例, HE 52 例に施行された. その結果を表 4 に示す. KS では全例 に精細管壁の硝子化を認め，46例では間質に Leydig 細胞の増殖を見た。43例（86\%）に精細管に生殖細胞 が存在しなかった。一部精細管に精子細胞，精子まで みられたものが各 1 例ずつ存在した。 10 代の $\mathrm{KS}$ 症例 7 名に扣いても全例, 精細管硝子化, 生殖細胞消失, Leydig 細胞増生を示す典型的な KS の睪丸組織像で あった。一方，HEでは精細管の硝子化は全く認めな かった。 37例（71\%）では小さな精細管に未熟な生殖 細胞と Sertoli 細胞のみが存在し, 間質に Leydig 細胞 の発育もない小児辠丸と同様の像を呈していた。しか し残りの15例では種々の程度の造精過程が認められ， 精子形成のある症例が 3 例存在した。思春期遅延症の 1 例では精子細胞まで, fertile eunuch 症候群の 1 例 では精子までが観察された。

III. 治療成績

治療およびその成績の概要を $\mathrm{KS}, \mathrm{HE}$ 別に表 5 にま とめた。

1) $\mathrm{KS}$ の治療

KS 67例中28名に対しテストステロン (T) 補充療法 を行った. 7 例は患者の希望により提供精液による人 工受精（AID）を受けるべく他院へ紹介した，32名に対 しては治療を行わなかった， T補充療法を行った 28 名 の治療成績を述べる。平均治療期間は 4 年で, $\mathrm{T}$ 療法 により15例で陰茎, 恥毛の発育, 勃起, 射精力の増強 
Table 5 Treatment

\begin{tabular}{l|c|c|c}
\hline & $\begin{array}{c}\text { number } \\
\text { of } \\
\text { patients }\end{array}$ & $\begin{array}{l}\text { duration } \\
\text { of therapy } \\
\text { (year) }\end{array}$ & $\begin{array}{l}\text { excellent } \\
\text { effect }\end{array}$ \\
\hline $\begin{array}{l}\text { Klinefelter's } \\
\text { syndrome } \\
\text { Testosterone }\end{array}$ & 28 & 4.0 & $15(54 \%)$ \\
AID & 7 & & \\
No therapy & 32 & & \\
\hline & 67 & & \\
\hline $\begin{array}{l}\text { Hypogonadotropic } \\
\text { eunuchoidism }\end{array}$ & & & \\
Gonadotropin & 27 & 1.8 & $10(37 \%)$ \\
Testosterone & 33 & 6.3 & $24(73 \%)$ \\
No therapy & 9 & & \\
\hline \multicolumn{2}{l}{} \\
\hline
\end{tabular}

など著明な二次性徵の発現をみている。1 年未満で治 療を中止してしまったものは 8 例であった，治療後 2 名が結婚し，既婚 28 名のうち 2 名が離婚した。

2) $\mathrm{HE}$ の治療

HE 69例中27例に hCG 療法を行ったが, このらち14 例は途中でT補充療法に変更した。33例では初めから T療法を行った。下垂体腫瘍の発見された 1 例では経 鼻的腺腫摘除術を行い, 術後にT療法を行ったのでこ の群に入れて取り扱った。残りの 9 例は当科では治療 を行わなかった。

HCG 療法を行った 27 例の平均治療期間は 1.8 年で ある。このうち 10 例で陰茎成長, 恥毛発育, 勃起, 射 精の発現, 辠丸下降または容量の増大, 血中 $\mathrm{T}$ 值上昇 などの満足な効果を認めた。治療後に射精可能となっ たものは 5 例あり，このうち 2 例では精液中に精子を 認めた。その 1 例は fertile eunuch 症候群と考兄られ る症例である。不十分ながら性器発育をみたものが 6 例，殆ど効果の無かったもの11例であった。14例は hCG 療法を中止し T療法に変更し，5例で二次性徵の 発育をみた。初めから T療法を行った 33 例の平均治療 期間は 6.3 年であった. 24 例に性器発育, 性能力増強な どの効果を認めた。このうち 1 例は思春期遅延症と考 えられる症例で，5 カ月間の $\mathrm{T}$ 療法で性器発育をみた ので，治療を中止したところ自然に二次性徴が完成し て，精液中に精子を認めるに至った。T補充療法後 8 例が結婚している。

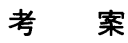

原発性殬丸機能不全症の代表的疾患である Kilinefelter 症候群（KS）と，間脳一下垂体病変によ
りゴナドトロピン分泌の障害された低ゴナドトロピン 性類宦官症 (HE) との臨床像をまず対比させて検討す る。初診時の平均年齢では $\mathrm{HE}$ は $\mathrm{KS}$ より若く，既婚 者が KS では HE より圧倒的に多く，また主訴は HE では性器発育不全が大部分，KS では性器発育不全と 不妊がほぼ半数ずつであった。 また体重，身長などで みる身体の発育，辠丸，陰茎の大きさ，恥毛の発生に 掞いても一般に HE の方が KS より辠丸機能障害が強 かった。このことは性器発育不全を示す患者を初診し た場合，その醉丸障害が原発性か続発性かを大まかに 鑑別するのに役立つと思われる.さらに KS, HE 鑑別 の助けになる特徵的な合併症状として，女性化乳房， 停留辠丸，知能障害，嗅覚異常などがある，女性化乳 房は KS の古典的な臨床上の特徵の一つとされている が, 染色体分析に基づいて診断された KS の集計では, 女性化乳房は本症必発の症状ではなく，著者らの成績

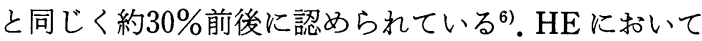
は女性化乳房は一般に未治療例では少ないといわれて いるが5)，これの合併する症例も報告されている77．停 留鼻丸の合併は著者らの $\mathrm{KS}$ 群では $8 \%$ \%゙った。染 色体のスクリーニング検查で発見された乳幼児の KS では停留辠丸の合併は $6.3 \%$ で一般の男子小児のそれ より高いと報告されている ${ }^{8}$. HE の停留䁄丸の合併は 著者らの HE 群では KS の 2 倍で，乙かも両側性が多 かった。停留殬丸は HE, 特にゴナドトロピン単独欠損 症の特徵的な臨床症状の一つである ${ }^{5) 9}$. 知能障害の合 併は KS では一般よりやや高く，知能障害者を母集団 とした統計では KS の発見率が高いといわれてい る $^{10)}$. KS の知能障害は X 染色体の数が増すと発生率 が高くなり ${ }^{11)}$, 著者らの KS 群でも $48, \mathrm{XXXY}$ の双生 児 1 組は知能低下を示した。

嗅覚障害を伴らゴナドトロピン単独欠損症は Kallmann 症候群として知られており, 脳の性機能整領域 と嗅覚に関与する嗅葉とが解剖学的に近いため脳の発 育異常により両者が合併するものと考光られる99. ま たゴナドトロピン単独欠損症では難聴，口唇裂，口蓋 裂，短指症などの先天性奇型を合併することがある。 遺伝的背景としては, KS では両親, 特に母親の年齢の 高さとその発生が関係するといわれている12)，HEで は Kallmann 症候群などのように家族発生するもの のあることが注目されている99.

辠丸機能不全症の鑑別診断上，染色体分析は極めて 重要な意味をもつ．KS は現今では 2 個以上の X染色 体と 1 個のY染色体を同一細胞内に有する性染色体異 
常と定義されている ${ }^{11}$ ．KS の染色体構成としては著 者らの KS 群に示されるように, $47, \mathrm{XXY}$ が最も多 く,さらに過剰X染色体の多い $48, \mathrm{XXXY,49,}$ $\mathrm{XXXXY} \mathrm{また46，XY/47，XXY} \mathrm{などのモザイクがあ}$ $3^{11)}$. HE の染色体は正常男子型 $46, X Y$ であり, 染色 体異常はない。

血中，尿中のゴナドトロピンは KS では辠丸からの feedback 欠如のため高值となり，HEでは低値とな $3^{122) 613)}$ 。 また外因性 LH-RH に対する血中 LH 招よ び FSH 值の反応は KS では過剩となり, HE では一般 に極めて少ないかまたは皆無となる2(5)7)14).これは KS と HE 鑑別の基本的内分泌特徵で, 著者らの成績でも 同様であった。しかし HE の血中 LH, FSH 基礎值打 よび LH-RH に対する反応には疾患または症例により 多少の差異が認められた。著者らの HE 群ではゴナド トロピン単独欠損症が大部分であるが，その他の種々 の原因による HE が一括されているためである，理論 的には LH-RH に対して LH, FSH の上昇反応のない ものは下垂体病変, 上昇の認められるものは, 下垂体 のゴナドトロピン分泌細胞には異常がなく, 間脳の障 害と考光られる ${ }^{5)}$. 多腺性下垂体ホルモン欠損症や下 垂体腫瘍では LH-RH により LH, FSH は殆ど反応せ ず，間脳視床下部の LH-RH の分泌調節異常によると 考えられているゴナドトロピン単独欠損症はある程度 反応があることになる。しかし本疾患に拈いても LHRH に対する LH, FSH の反応態度には多様性があ り, 両者とも反応, 両者とも無反応または一者のみ反 応などがあると報告されている ${ }^{14)}$.ゴナドトロピン単 独欠損症の中です LH, FSH それぞれの分泌障害程度 は一様でなく, そのため血中下值抢よび二次性徵, 造 精能の発育などの臨床像にも差が現われる14)15). 本疾 患と鑑別困難な HE として思春期遅延症と fertile eunuch 症候群がある.

思春期遅延症患者は思春期に二次性徵発育不全を訴 えて受診することが多く，血中 LH，FSH 值は小児な みの低值であるが，しばらく経過を観察しているとま ず FSH 值の軽度上昇と LH-RH に対する反応が現わ れ, 囯丸容量が増加してくる. 次いで $\mathrm{LH}$ 上昇, $\mathrm{T}$ 上 昇に伴い二次性徵が徐々に発達するといら正常な思春 期の身体変化が正常より遅れて完成する，本疾患は体 質的な思春期の遅れで，間脳視床下部の性中权成熟の 何等かの異常之考えられている5 . 正確な診断には数 年の経過観察が必要である。

Fertile eunuch 症候群は辠丸の大きさが葟注正常で
精子形成能が比較的よく保たれているにも拘わらず Leydig 細胞の発育が悪く男性二次性徴の欠如を示す。 本症では下垂体のFSH は正常に分泌されているが LH は低値または検出不能の症例が多く, 原因として LH の単独欠損が考劣られた ${ }^{16)}$. Fertile eunuch 症候 群では一般に LH-RH に対する LH および FSH の反 応は典型的なゴナドトロピン単独欠損症より良好 で17), 我々の症例のように血中 LH が葟涪正常で, LHRH によく反応する症例も報告されている ${ }^{18)}$. 精子形 成能が完成するには FSH のみならずTの作用も必須 なので19), fertile eunuch 症候群でも LH が完全に障 害されているとは考劣にくい，本症候群は思春期発来 の初期に FSH 上昇と僅かの LH 上昇で造精機能が発 達し，間脳視床下部の何等かの異常で，次いで起こる べき LHの急上昇が遅れたまま留まった状態とも考 えられる。このように考えると, fertile eunuch 症候 群，思春期遅延症，ゴナドトロピン単独欠損症の間に 臨床像上，様々の移行型が存在することがよく理解で きる17).

血中 Tの値は $\mathrm{KS}, \mathrm{HE}$ とも正常男子に比べて有意に 低いが，HEのT平均値はKSのそれよりさらに低 かった．KS の中には正常值を示すものも数例存在す る.このことは臨床的に HE がより性器発育不全の症 状が強いこと，KS では結婚して不妊以外には愁訴も なく正常な性生活を営んでいるものがかなり存在する といら事実とょく一致している，HCGに対する血中 Tの反応は, KS では正常男子に比べて前值, 反応値と も低かった。これは外因性ゴナドトロピンに対する睪 丸 Leydig 細胞の予備能が KS では少ないことを意味 し，既に内因性の LHにより十分刺激されているため と考えられる.一方, HE では $\mathrm{T}$ 基礎值拀よび最高反応 值が KSよりさらに低かったが，前值に比べょく反応 して括り，反応率は正常男子ょりむしろ大であった。 これ迄の報告から考学ると，HEにおいて短期間の hCG 試験での Tの反応が小さいのは, Leydig 細胞の 反応性に欠陥があるのでなく，Leydig 細胞が外因性 hCG に反応するには，予めゴナドトロピンにより刺激 をらけて priming されていなければならないためで あろ ${ }^{7) 20)}$ 。このためある程度まで睪丸成熟の進んだ fertile eunuch 症候群のような症例では hCGに対す

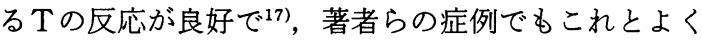
一致した。

PRL の分泌は他の下垂体ホルモンとは異なり，視床 下部のドーパミンによって抑制的に調節されているの 
で，この部分の病変では高 PRL 血症を生ずることが ある. KS のような原発性殬丸障害では血中 PRL 値に 特別な異常を示さないが，HEではその病変が間脳一 下垂体系に存在するので, 血中 PRL 值および TRH に対する異常反応を生ずることがある ${ }^{4)}$. 著者らは下 垂体腺腫摘除後もな扮高 PRL 血症が続き殬丸機能低 下を示した 1 例と, 性器発育不全を主訴として来院し, 高 PRL 血症のため精查を行い, 下垂体 microadenoma と診断した 1 例とを経験した。

醉丸組織像も KS, HE そそれぞれ特徵的な所見が認 められる。精細管の硝子化, 生殖細胞の消失, 間質に おける Leydig 細胞の結節様増生が KS の睪丸組織像 の特徵である ${ }^{5111}$ 。 この変化は思春期以後に明らかに なり，小児期には同年の正常男児とほとんど変りがな いといわ机ている ${ }^{8)}$. 著者らの今回の KS 群には10代 症例が 7 名存在したが, すべて15歳以上であったため 鼻丸の障害はすでに成人例と同様に進行していた。一 般に年齢の進んだ症例では辠丸組織障害の程度が大き く，また過剩X染色体の数が多くなると障害が増すと いわれている ${ }^{11)}$. KS の造精機能障害には症例により 多少差があり, 著者らの KS 群では 7 例で生殖細胞が 保たれていた。このように KS で造精能のある精細管 が残っていることは決して稀ではなく, 精液中に精子 を認める症例も報告されている6111). 間質の Leydig 細 胞は見掛け上の増殖を示すのみで，辠丸全体としては その数も少なく，それぞれの Leydig 細胞にも機能障 害があると考兄られる ${ }^{11}$. 一方, HE の醉丸組織には精 細管硝子化は認められず，大部分は小児の睪丸の上う な末熟な像を呈した。しかし HE 群中15例は精子形成 過程がある程度進行しており, 精細管に精子まで認め られるものも 3 例あった. HEの睪丸組織所見も中枢 の障害の程度により様々で, 特に fertile eunuch 症候 群と考えられる症例ではほぼ完全な精子形成を示すこ とが知られている ${ }^{16)}$.

殬丸機能不全症の治療方針を $\mathrm{KS}, \mathrm{HE}$ に分けて考兄 る。すず KS は性染色体異常に基づく不可逆的な精細 管障害がその疾患の本質なので, 妊孕性に関しては現 在のところいかなる治療法も有効たり得ない，従って アンドロゲン補充療法が治療の主体となる，著者らが アンドロゲンデポ剤筋注により T補充療法を行ったの は KS 67例中 28 例であった。 このうち15例, 半数以上 に抢いて陰茎, 前立腺の発育, 体毛, 陰毛の発生, 声 变り, 筋肉の発育拉よび男性的体格の形成, 性欲, 勃 起力の増強などの臨床効果が得られた。 Tデボ阂の投
与は $\mathrm{KS}$ 患者の血中T値を上昇させまた異常高値にあ る LH, FSH 值を下降させて, 上記のような臨床効果 をもたらす ${ }^{13)}$ 。さらにT補充療法は KS に扔いて身体 的治療効果のみならず，積極的で活発な性格を形成す るなどの精神的効果ももたらすと言われている21)。乙 かし一方では著者らの KS 群には 1 年未満でT療法を 中止してしまったものが 8 例あった。これは患者に対 する治療目的の説明不足で治療効果が患者の期待どお りでなかったり，女性化乳房の増強，体重の著増など の副作用の出現のためである，不妊を主訴とした患者 で性器発育不全がそれ汪ど顕著でなく，血中下值も正 常に近い場合には, T補充療法は必要でない。

$\mathrm{HE}$ の治療としてゴナドトロピン療法，テストステ ロン補充療法, LH-RH 療法がある.

ゴナドトロピン療法は HE に対して最も一般的に 行われる治療法である。著者らの HE 群67例中 27 例に hCG 療法を行い, その中10例に醉丸重量の増大, 停留 睪丸の下降, 血中 $\mathrm{T}$ 值の上昇に伴って陰茎の増大を初 めとする副性器の発育, 身体の男性的発育, 性欲, 勃 起，射精力の増強をみるなど満足な成績を得た。しか しこれらの完成には 1 年近くの期間を要した。今回の 成績では hCG 療法により精液中に精子を認めたのは 2 例のみであった。精子形成過程で精子細胞の成熟に は FSH が必要とされるので造精機能の改善には LH 作用をもつ hCG のみでなく, FSH 作用をもつ human menopausal gonadotoropin (hMG) を併用する必要 がある22223). Fertile eunuch 症候群のようなゴナドト ロピンの部分的欠損では hCG のみでも精子形成が完 成するが，一般の HEでは hCGにより二次性徵を発 育させて，妊孕性の必要とされた時点で hMG を併用 する方法も考号られている5 . 著者らの $\mathrm{HE}$ 群で $\mathrm{hCG}$ 療法を行った 27 例中半数以上の 14 例が，二次性徵発現 効果が不満足なため治療を中止した。ゴナドトロピン 単独欠損でも hCG 療法に良好に反応寸るものと, 抵抗 性のあるもののあることが知られている ${ }^{24) 25)}$ ，一部の 症例では長期 $\mathrm{hCG}$ 療法を続けたことにより産生され た hCG 抗体が治療に抵抗性を示すためと考兄られ $ろ^{26)}$.

HE に対するT補充療法を著者らは hCG 療法に効 果を認めなかった14症例扣よび妊孕性を諦め二次性徵 出現のみを期待した 33 症例に行い, $3 / 4$ の症例で満足な 結果を得た. Burger ら ${ }^{27)}$ は HE の 3 例に対しまずTを 投与して二次性徵を完成させ, しかる後に $\mathrm{hCG}$ を用い て造精機能を導入し，妊孕性を獲得させたと報告して 
いる. 著者らは思春期遅延症の 1 例に対し， 5 力月間 下療法を行い, これにより二次性徵の発来をみたので 治療を中止し, その後自然に内分泌機能と造精能が正 常化した経験をもつ. 前述のように思春期遅延症は経 過を及るらちに自然に思春期が発来し完成するといわ れている。しかし実際の臨床上にはゴナドトロピン単 独欠損症と鑑別困難であり, また性器発育不全が患者 に与える心理的影響が極めて大きいので何らかの治療 をせをられる場合が多い， T療法を $3 \sim 6$ 力月行い, 二次性徴の発現をみたらすぐこれを中止するといら試 みがなされることがある5). この程度の短期間の T投 与はHEに対して精細管の不可逆的变化はおこさな いという報告がある27)。

ゴナドトロピン単独欠損症は間脳視床下部に扣ける LH-RH の合成あるいは放出に欠陥があると考兄られ ているので, この疾患の最も理論的な治療法は LH. RH の投与といらことになる. 事実, 合成 LH-RH の経 時的皮下注射による治療の試みも報告されている28).

しかしその後の研究で合成 LH-RH は初めは LH お よび FSH の分泌刺激を生じ，内分泌機能も賦活され るが，治療を継続すると逆に LH，FSH の分泌を抑制 し，血中 LH，FSH 值を下げて血中Tを去勢レベルに まで低下させるという逆説的鼻丸機能抑制現象が確認 され，最近では合成 LH-RH はむしろ辠丸機能抑制の 目的で用いられている29).

以上の成績に基づき著者らは辠丸機能不全症の治療 方針を次のように考える．KSでは性器発育が正常に 近いものに対しては，ホルモン療法は行わない。患者 の知能，性格に応じて疾患内容を説明し，妊孕性に関 しては望みのないことを告げる. 二次性徵発育が不十 分なものに対してはT補充療法を行う. HEに対して は14〜15歳迄は経過を観察し，この年齢を過ぎても思 春期の徵候が全く現われない場合には hCG 療法を開 始する。 二次性徵が完成されても造精機能が不十分な 場合には hMG を追加する. HCG で効果の無い症例に 対してはT療法を行う。

本論文の要旨は1985年第73回日本泌尿器科学会総会, シ ンポジゥム“性分化の基礎と臨床”で発表した。

\section{文献}

1) Fukutani, K., Isurugi, K., Takayasu, H., Wakabayashi, K. amd Tamaoki, B.: Effects of depot testosterione therapy on serum levels of luteinizing hormone and follicle-stimulating hormone in patients with Klinefelter's syndrome and hypogonadotropic eunuchoidism. J.
Clin. Endocrinol. Metab., 39, 856-864, 1974.

2) Isurugi, K., Wakabayashi, K., Fukutani, K., Takayasu, H., Tamaoki, B. and Okada, M.: Responses of serum luteinizing hormone and follicle stimulating hormone levels to synthetic luteinzing hormone-releasing hormone (LH$\mathrm{RH}$ ) in various forms of testicular disorders. J. Clin. Endocrinol. Metab., 37, 533-539, 1973.

3）石田 肇, 岩動孝一郎, 福谷恵子, 細井康男, 高安 久雄: 各種男子性腺機能不全括よび性分化異常疾 患に拈ける hCG テストについて. 日泌尿会誌, 69, 6-14, 1977.

4）加藤 譲：プロラクチン分泌機能検査. 木と臨, 31 増刊, 17-22, 1983.

5) Griffin, J.E. and Wilson, J.D.: Disorders of the testis and male reproductive tract. In Textbook of Endocrinology, 7th ed. p. 259-298, Saunders Co., Philadelphia, 1985.

6）布施秀樹, 皆川秀夫, 伊藤晴夫, 島崎 淳, 片山 喬：Klifelter 症候群の臨床的観察. 日泌尿会誌, 74, 226-234, 1983.

7) Boyar, R.M., Finkelstein, J.W., Witkin, M., Papen, S., Weitzman, E. and Hellman, L.: Studies of endocrine function in "isolated" gonadotropin deficiency. J. Clin. Endocrinol. Metab., 36, 64-72, 1973.

8) Ratcriffe, S.G.: The sexual development of boys with the chromosome constitution 47, XXY (Klinefelter's syndrome). J. Clini Endocrinol Metab., 11, 703-714, 1982.

9) Santen, R.J. and Paulsen, C.A.: Hypogonadotropic eunuchoidism. I. Clinical study of the mode of inheritance. J. Clin Endocrinol. Metab., 36, 47-54, 1973.

10) Perwein, E.: Incidence of Klinefelter's syndrome. in Klinefelter's Syndrome, Bandmann, H-J. and Breite, R., p. 8-11, Springer-Verlag, 1984.

11）木川源則, 大島博幸：性の分化と異常. p. 50-58, 医歯薬出版, 東京, 1983.

12) Murken, J. and Stengel-Rutkowski, S. : Klinefelter's syndrome in parental diagnosis: Incidence and consequence for genetic couselling. In klinefelter's Syndrome, Bandmann, H-J. and Breit, R., p. 24-28, Springer-Verlag, 1984.

13）福谷恵子：Klinefelter 症候群に打ける間脳一下 垂体一殬丸系の内分泌学的研究. 日泌尿会誌, 67, 954-967, 1976.

14) Bell, J., Spitz, I., Slonin, A., Perlman, A., Segal, S., Palti, Z. and Rabinowitz, D.: Heterogenicity of gonadotropin response to LHRH in hypogonadotropic hypogonadism. J. Clin. Endo- 
crinol. Metab., 36, 791-794, 1973.

15) Boyar, R.M., Wu, R.H.K., Kapen, S., Hellman, L., Weitzman, E.D. and Finkelstein, J.W. : Clinical and laboratory heterogenicity in idiopathic hypogonadotropic hypogonadism. J. Clin. Endocrinol. Metab., 43, 1268-1275, 1976.

16) Faiman, C., Hoffman, D.L., Ryan, R.J. and Albert, A.: The "fertile eunuch" syndrome: Demonstration of isolated luteinizing hormone deficiency by radioimmunoassay technique. Mayo Clin. proc., 43, 661-667, 1968.

17) Smals, A.G.H., Klopopenborg, P.W.C., van Haest, U.G.J., Lequin, R. and Benraad, T. : Fertile eunuch syndrome versus classic hypogonadotropic hypogonadism. Acta Endocrinol., 87, 389---399, 1978.

18) del Pozo, E., Bolté, E. and Very, M. : Suprasellar distrubance in the syndrome of fertile enunuchoidism : Case report. Acta Endocrinol., 80, 165-170, 1975.

19) Winter, J.S.D. and Faiman, C.: Pituitarygonadal relationship in male children and adolescent. Pediat. Res., 6, 126-135, 1972.

20) Santen, R.J. and Paulsen, A.: Hypogonadotropic hypogonadism. II. Gonadal responsivencess to exogenous gonadrotropins. J. Clin. Endocrinol. Metab., 36, 55-63, 1973.

21) Nielsen, J. and $\mathrm{S} \phi$ rensen, K. : The importance of early diagnosis of Klinefelter's syndrome. In Klinefelter's Syndrome , Bandmann, H-J. and Breite, R. p. 170-187, Springer-Verlag, 1984

22）岩動孝一郎：Gonadotropin deficiencyによる男 子 hypogonadism 症例に対する hCG/hMG 併用 療法についての検討. 日不妊学会誌, 28, 189-196, 1983.
23）奥山明彦, 並木幹夫, 小出卓夫, 園田孝夫, 宇都宮 正登, 伊東 博, 吉岡俊昭, 板谷宏樹, 西本直光, 水谷修太郎：睪丸間質機能の検討. 第 8 報：低ゴ ナドトロピン性性腺機能低下症に対するゴナドト 口ピン長期投与の経験. 日泌尿会誌, 74, 1205-1212, 1983.

24) Check, J.H., Caro, J.F., Criden, L., Meltz, R. and Brownstein, K.: Leydig cell responsiveness with germinal cell resistance to gondotropin therapy in Kallman's syndrome. Amer. J. Med., 67, 495-497, 1979

25）近藤福次, 藤井敬三, 岡村康晴, 徳中荘平, 高村孝 夫, 八竹 直: Kallmann 症候群の 2 例。泌尿紀 要, 32, 192-134, 1986.

26) Sokol, R.Z., McClure, R.D., Peterson, M. and Swerdloff, R.S. : Gonadotropin therapy failure secondary to human chorionic gonadotropininduced antibodies. J. Clin. ENdocrinol. Metab., 52, 929-933, 1981 .

27) Burger, H.G., de Kretster, D.M., Hudson, B. and Wilson, J.D. : Effects of preceding androgen therapy on testicular responce to human pituitary gonadotropin in hypogonadotropic hypogonadism : A study of three patients. Fertil Steril, 35, 64-68, 1981.

28) Mortimer, C.J., McNeilly, A.S., Fisher, R.A., Murray, M.A.F. and Bessor, G.M.: Gonadotropin-releasing hormone therapy in hypogonadal males with hypothalamic or pituitary dysfunction. Brit. Med. J., 4, 617-621, 1974.

29）岩動孝一郎：LH-RH アナログ製剤の臨床応用に ついて一特に前立腺癌を中心にして一. 臨泌，39， 635-644, 1985.

（1986年 3 月 7 日受付） 